\title{
下部尿路の尿流動態研究
}

\author{
II . 排尿パラメーターのコンピューター分析

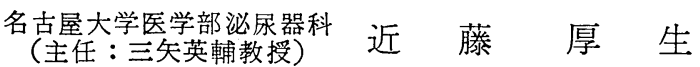

\section{URODYNAMIC STUDY OF LOWER URINARY TRACT}

II. Computer Analysis of Micturition Parameters

\author{
Atsuo Kondo \\ Department of Urology, Nagoya University School of Medicine, Nagoya, Japan
}

(Director: Professor Hideo Mitsuya)

Thirty-five micturition parameters of urinary flow curves have been statistically evaluated by computer analysis. The flow rate and urinary volume voided were calculated every second by the analysis of flow curve. Parameters involve the correlation found among flow rate, total urinary volume, volume voided each second, voiding time and sex. A flow curve, obtained through Mictiograph (DISA, 14F43), was photographed and mounted on a slide. Enlarged curve by a slide projector was plotted every second with Graph pen, which was simultaneously recorded on teletype printer. 249 flow curves out of 500 obtained in 150 healthy male and female volunteers aged from 18 to 45 were fed into a digital computer.

Experimental study of the accuracy of Mictiograph demonstrated that the change in urinary stream velocity and centripetal force on the rotating disk had yielded a significant error upon its flow rate and the subsequent total urinary volume computed in the present study. The response to change in urinary volume alone was quite satisfactory. The volume coefficient (computed urinary volume/real urinary volume) was found spread between 0.5 and 1.3. Reliability of data to be utilized for computer analysis was defined to be \pm 15 percent of volume coefficient, which further reduced the number of flow curves from 249 to 176 .

1) Total urinary volume, average flow rate and maximum flow rate: they are all proportional to the total urinary volume in both sexes. Significant difference between sexes was found only at the maximum flow rate; the values are higher in females than in males.

2) Time and time percent at maximum flow rate: the time at maximum flow rate is correlated with the total urinary volume in males, but not in females. Flow rate reaches the maximum in one third of total voiding time.

3) Volume and volume percent until time of maximum flow rate: the former is proportinal to the total urinary volume in both sexes. Approximately 40 percent of total urinary volume is voided within this period.

4) Volume and volume percent for the first 1 to 5 seconds: the former is correlated with the total urinary volume. During the first 5 seconds 70 percent of total volume is evacuated in the group of 50 to $99 \mathrm{ml}$, while only 25 percent in the group of 400 to $499 \mathrm{ml}$.

5) Correlation between voiding time and volume voided: Regardless of sex and total urinary volume, 25 percent of total volume is voided in one fifth of total voiding time, 50 percent in one third and 75 percent in one half.

6) In general females have a stronger urinary stream force than males.

7) A drop is observed in the flow rate curve at 1 to 5 seconds in males and at 2 and 3 seconds in females. No significant meaning can be drawn from this phenomenon.

8) Mictiograph is one of the valuable clinical tools to evaluate the mode of micturition qualitatively. However it possesses a certain intrinsic limitation as a method for the quantitative analysis of micturition parameters. 


\section{諸言}

尿波形測定 (uroflowmetry) は今日泌尿器科領域で頻 繁に使用され，日常診療に叔ける検査法として欠くべ からざる地位を確立した。1974年より我々は尿流量計 Mictiograph（DISA，14F43) を外来・入院患者に使用 しているが，排尿障害のパターンは直ちに識別でき，更 に薬物療法・外科治療の効果は客観的に分析可能となつ た。この検査法の他の長所は患者に苦痛を与兄ない，尿 道・膀胱へカテーテル插入を要しない，操作が簡便でし かも短時間で完了する等々である.

最大排尿率, 平均排尿率, 総排尿時間の各排尿パラメ 一ターに関する定量的分析結果 ${ }^{12)}$ ，扩よび 種々尿路疾 患に打ける排尿曲線の定性的変化 ${ }^{3) 45}$ 亿多いいてはすでに 多く報告されている。しかし経時的排尿量についての詳 細なデータは報告されていない，今回は健康人の排尿曲 線よりコンピューターを用いこの経時的排尿量の変化と 排尿率，総排尿時間を計算し，性別，総排尿量との相 関について統計的分析を抗こなつたので報告する。なお Mictiograph の精度については松田等 ${ }^{6)}$ がすでに本誌上 で発表しているが，この研究途上解明された機構上の本 質的欠宿についても検討を加える。

\section{対象と方法}

検查対象は 18 歳から 45 歳の 健康人，男女 150 名であ る. その構成は名古屋大学学生, 名古屋大学病院拈よび 中部労災病院附属高等看護学院学生, 医師, 看護婦, 下 路尿路に障害を有さない患者が主である。

排尿曲線は尿流量計 Mictiograph（DISA，14F43) を 経て入手した。 Mictiograph は次のような作働原理を有 している．尿流トランスデューサー(uroflow transducer) には一定数にて回転する縁付円盤（直径 $70 \mathrm{~mm}$ ，外縁 高 $7 \mathrm{~mm}$ ，重量 $6 \mathrm{~g}$ ）が接続している。この円盤上に負荷

（尿流量）が加わると回転数は瞬時低下するが，電気回 路に組みこまれたサーボ機構の働きで余分の電流を消費 し回転数を一定に保つ．電流消費量の变化を微分し記録 紙に描出したものが排尿曲線である，総排尿量は記録紙 の終末に表示され，これは余分に消費した電流総量に等 しい.しかし今回の研究ではこの総排尿量表示が不正確

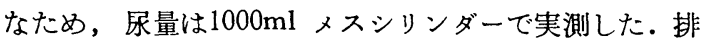
尿率は全例 $50 \mathrm{ml} / \mathrm{sec} / 50 \mathrm{~mm}$ の目盛で測定し，記録紙速 度は $3 \mathrm{~mm} / \mathrm{sec}$ であつた。排尿は腹生を加えておこなら よう要請した。尿流量計と女子用排尿台は隔離室に設置 し，周囲からの心理的要因を除去するょら配虑した。男 子は立位で排尿し，外尿道口と回転円盤との 距離は約
$30 \mathrm{~cm}$ とした，女子は日本女性の一般的排尿姿勢を考慮 し，特製排尿台を作り踇踞位で排尿させた．前方に排出 孔を有する和風大便器（伊奈, C-102）を用い, 前方に 10 度傾斜させ床高 $61 \mathrm{~cm}$ の排尿台 $(100 \times 110 \mathrm{~cm})$ に設 置した．排尿時に心理的安定感を与えるため台の前方に 遮蔽板 $(100 \times 37 \mathrm{~cm})$ を立て，これにロールペーパーを 装着した。排出孔直下に尿流トランスデューサーを拀 き，女子外尿道口からの距離は約 $40 \mathrm{~cm}$ となる。

\section{排尿曲線のコンピューター解析}

150 名の健康人が 1 〜数回排尿し, 500枚の排尿曲線が 得られた。排尿パラメーターは総排尿量と強い相関を示 すといわれ ${ }^{2}$ ，又女子の排尿は解剖学的差異より男子と は当然異なる．排尿曲線をまず性別により 2 群に分け， 更に実測尿量で次の 5 群に分類した。すなわちグルー プ I は50〜99ml，グループII は100〜199ml，グルーブ III は200〜299ml，グループIVは300〜399ml，グループVは 400 499ml である (Table 1). 排尿量 $49 \mathrm{ml}$ 以下および

Table 1. Five groups of urinary volume and number of data. 249 flow curves out of 500 were first fed into computer. When the error of these data was taken into account, the number of data was reduced from 249 to 176 .

\begin{tabular}{c|c|c|c|c}
\hline $\begin{array}{l}\text { Group (Range } \\
\text { of urinary } \\
\text { volume })\end{array}$ & \multicolumn{2}{|c|}{$\begin{array}{c}\text { Data fed into } \\
\text { computor }\end{array}$} & \multicolumn{2}{c}{$\begin{array}{c}\text { Final number for } \\
\text { computor analysis }\end{array}$} \\
\cline { 2 - 5 } & Male & Female & Male & Female \\
\hline $\begin{array}{c}\text { I } \\
(50 \sim 99 \mathrm{ml})\end{array}$ & 19 & 12 & $\begin{array}{c}15 \\
(70 \mathrm{ml})^{*}\end{array}$ & $\begin{array}{c}7 \\
(74 \mathrm{ml})\end{array}$ \\
\hline $\begin{array}{c}\text { II } \\
(100 \sim 199 \mathrm{ml})\end{array}$ & 29 & 41 & $\begin{array}{c}23 \\
(149 \mathrm{ml})\end{array}$ & $\begin{array}{c}25 \\
(136 \mathrm{ml})\end{array}$ \\
\hline $\begin{array}{c}\text { III } \\
(200 \sim 299 \mathrm{ml})\end{array}$ & 30 & 47 & $\begin{array}{c}22 \\
(241 \mathrm{ml})\end{array}$ & $\begin{array}{c}26 \\
(228 \mathrm{ml})\end{array}$ \\
\hline $\begin{array}{c}\text { IV } \\
(300 \sim 399 \mathrm{ml})\end{array}$ & 28 & 24 & $\begin{array}{c}26 \\
(338 \mathrm{ml})\end{array}$ & $\begin{array}{c}17 \\
(317 \mathrm{ml})\end{array}$ \\
\hline $\begin{array}{c}\text { V } \\
(400 \sim 499 \mathrm{ml})\end{array}$ & 13 & 6 & $\begin{array}{c}10 \\
(421 \mathrm{ml})\end{array}$ & $\begin{array}{c}5 \\
(437 \mathrm{ml})\end{array}$ \\
\hline Subtotal & 119 & 130 & 96 & 80 \\
\hline Total & \multicolumn{2}{|c|}{249} & & \multicolumn{2}{c}{176} \\
\hline
\end{tabular}

* Mean urinary volume of each group.

$500 \mathrm{ml}$ 以上は正常排尿パターンを示さずこれらの資料は 棄却した。排尿曲線の余白に氏名，性別，実測尿量，湘 定年月日を記入し，これを一定距離より写真撮影しスラ イド（ライカ版）を製作した。スライドをスライドプロ ジェクターにて，グラフペン (Science Accessory Corp, GP-2） XY 座標值測定盤に拡大投影寸る．拡大率は 3.3 倍すなわち排尿曲線横軸上の $3 \mathrm{~mm}$ (1 秒) をX軸上の $10 \mathrm{~mm}$ に拡大寸る．グラフペンを用い排尿曲線の立ち上 
Fig. 1. Enlarged flow curve is plotted by Graph pen every second, which subsequently calculates flow rate and urinary volume.

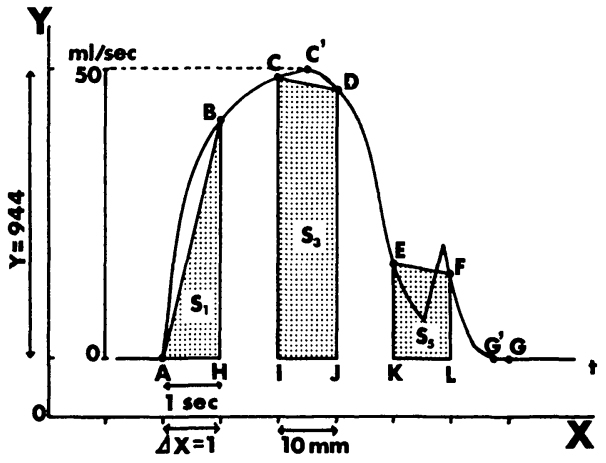

Table 2. 35 parameters obtained by computer analysis.

1. Total voiding time (sec)

2. Computed total urinary volume $(\mathrm{ml})$

3. Volume coefficient (computed volume/real volume)

4. Average flow rate (parameter $2 /$ parameter 1 ) $(\mathrm{ml} / \mathrm{sec})$

5. Maximum flow rate $(\mathrm{ml} / \mathrm{sec})$

$6 \sim 7$. Time (sec) and time $\%$ at maximum flow rate

$8 \sim 9$. Volume (ml) and volume $\%$ until time of maximum flow rate

10 19. Volume (ml) and volume $\%$ for the first 1 to 5 seconds

$20 \sim 25$. Time (sec) and time $\%$ at 25,50 and $75 \%$ - total volume

$26 \sim 35$. Flow rate at $1,2,3,4,5,6,7,9,11,13 \& 15$ seconds

りから最終点まで $10 \mathrm{~mm}$ 毎に曲線に忠実に追従し (Fig.

1), 各点のデータを $\mathrm{XY}$ 座標值としてテレタイププリ ンター (Teletype Corp, ASR-33) により紙面に印刷し 同時に紙テープに穿孔記録する。この紙テープ上のデ ータをプログラムにしたがいデジタルコンピューター (DEC Corp, PDP-12) に入力する。最後に男女各 5 群 での35パラメーター (Table 2) についてその平均值, 標準偏差, 最大值, 最小值をコンピュータープログラム により求めた.

コンピューター解析による排尿率 $(\mathrm{ml} / \mathrm{sec})$, 排尿時 間 $(\mathrm{sec})$ ，排尿量 $(\mathrm{ml})$ の計測は次の方法でおこなつた

(Fig. 1). 排尿曲線上の值のすべては第一点 $\mathrm{A}$ 点の $\mathrm{XY}$ 座標值を基準とする．ただし，Yのマイナス值は棄却す る.拡大投影された排尿曲線と XY 座標の関係により， $944 \mathrm{Y}=50 \mathrm{ml} / \mathrm{sec}$

$$
\mathrm{Y}=\frac{1}{18.1} \mathrm{ml} / \mathrm{sec}
$$

となる。一方 X軸上の各点間の距離は 1 秒である. した がつて,

$$
\Delta \mathrm{X}=1
$$

となる．最大排尿率は公式（1）により C 点 $\mathrm{Y}$ 座標值と $\mathrm{A}$ 点のY 座標值との差を18.8で除した商である . 総排尿時 間 $\mathbf{T}$ は曲線上の点数 $\mathrm{nから} 1$ を引いた差である。すなわ ち $\mathrm{AG}$ 間の時間は

$$
\begin{aligned}
\mathrm{T} & =\mathrm{n}-1 \\
& =7-1 \\
& =6
\end{aligned}
$$

となり 6 秒である. 総排尿量は本来排尿曲線 $\mathrm{f}(\mathrm{x})$ を積 分した值 $\mathrm{S} て ゙$ 求められる.

$$
\mathrm{S}=\int \mathrm{f}(\mathrm{x}) \mathrm{dt}
$$

今回は曲線 $f(x)$ を 1 秒毎に分割して得られる三角形お よび台形の面積総和により近似值として求めた。 $\mathrm{S}_{1}$ と $\mathrm{S}_{3}$ は次の上うに求める

$$
\begin{aligned}
\mathrm{S}_{1} & =\frac{\mathrm{BH} \cdot \mathrm{AH}}{2} \\
& =\frac{\mathrm{BH}}{2} \\
\mathrm{~S}_{3} & =\frac{(\mathrm{CI}+\mathrm{DJ}) \cdot \mathrm{IJ}}{2} \\
& =\frac{\mathrm{CI}+\mathrm{DJ}}{2}
\end{aligned}
$$

故に Fig. 1 の総面積 $\mathrm{S}^{\prime}$ は,

$$
\begin{aligned}
S^{\prime} & =\int_{A}^{G} f(x) d t \\
& \doteq \sum_{i=1}^{=6} S i
\end{aligned}
$$

コンピューター測定尿量Vは公式 (1)，(2)，(3)，(4),

(5)により

$$
\mathrm{V}=\sum_{i=1}^{i=n-1} \mathrm{Si} \times \frac{1}{18.8}
$$

平均排尿率 AFR は公式 (3)と（6)により

$$
\begin{aligned}
& \mathrm{AFR}=\frac{\mathrm{V}}{\mathrm{T}} \\
& =\sum_{i=1}^{i=n-1} \operatorname{Si} \times \frac{1}{18.8(n-1)}
\end{aligned}
$$

となる。

当初500枚の排尿曲線より男女各グループ毎に30枚を 無作為に抽出し 300枚を統計処理する 計画を立てた。し かし男子ではグループI と V，女子ではグループI， $\mathrm{IV}, \mathrm{V}$ で資料数が30枚に満たなかつた．そこで282枚を グラフペンにより分析したが，グラフペンの誤作動, 誤 操作のため33資料が無効となり，残る249資料（男119, 女130)のデータをコンピューターへ入力した (Table 1, 左).

コンビューター測定尿量と実測尿量との 相関は公式 （6）の妥当性を倹定するのみでなく，Mictiograph の精 
Fig. 2. Volume coefficient (computed urinary volume/real urinary volume) calculated in 249 flow curves is spread between 0.5 and 1.3 .

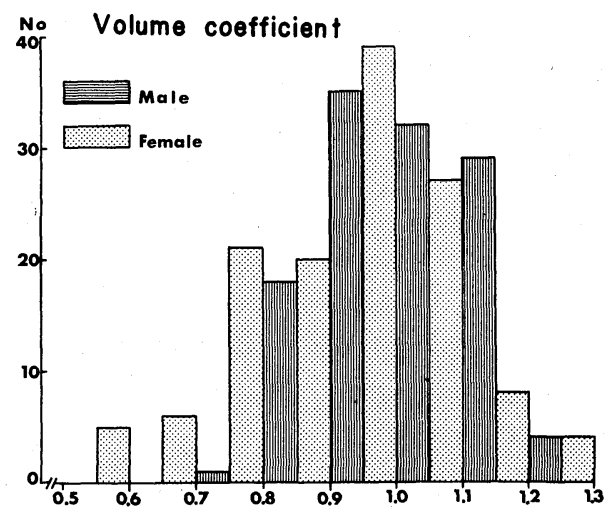

度を含めた一連の分析手技の信頼性をも反映するもので ある、そこでュンピューター 測定尿量を実測尿量で除 し，排尿量係数（volume coefficient）をすべての資料 で計算しヒストグラムに示した（Fig. 2)，排尿量係数 は0.5〜1.3の範囲に分散している. 男女の最頻数（モー ド）はいずれも 0.9〜1.00間に在る. 男子では係数 1.0 以上に 65資料，1.0以下に 54 と ほぼ同数が分布してい る.一方女子では各々 39 と 91 が分布し, コンピューター 測定尿量が実測尿量より少なく計算された資料が多い。 係数1.0又はそのごく周辺に資料が集約されていない事 実は Mictiograph の精度に欠陷があるか，又はそれ以後 の過程に括ける操作ミスの存在を示唆するものである. 後に述べる理由に基ずきュンピューター解析した資料の 誤差を土15\%に限定し，排尿量係数0.85～1.15の範团内 のデータを採用した。このため73資料が更に棄却され， 最終的資料数は 176 （男96，女80）となつた（Table 1, 右). 統計的有意差検定は最小 2 乗法, $x_{2}$ 検定, $t$ 検定 法を用いた。

\section{排尿パラメーター}

1. 総排尿時間 (total voiding time)

グループ I では約10秒，グループVでは約 20 秒で排尿 が完了する (Fig. 3).このグラフは明らかに一定の増加 傾向を示す，そこで最小 2 乗法により傾向線を求めた。 男女の傾向線は,

$$
\begin{aligned}
& y=3.3 x+6.5 \\
& y=2.4 x+7.4
\end{aligned}
$$

となり各々有意であつた $(0.01>\mathrm{p})$. 男子は一般に女子 より排尿時間が長いが，男女間の傾向線には有意差を認
Fig. 3. Total voiding time is proportional to total urinary volume in both sexes.

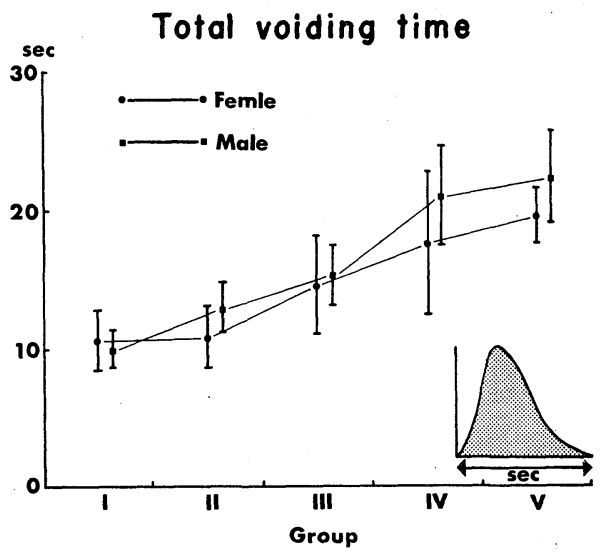

めない $(p>0.05)$. y は時間 (sec), $\mathrm{x}$ はグループを示 †.

2. 平均排尿率 (average flow rate)

総排尿量 と正の 相関を有し，グループVの平均排尿 率，19〜23ml/sec はグループ I , $7 \mathrm{ml} / \mathrm{sec}$ の約 3 倍であ る (Fig. 4, 左).男女の傾向線は,

$$
\begin{aligned}
& y=2.9 x+5.4 \\
& y=3.8 x+4.3
\end{aligned}
$$

となり各々有意であつた $(0.01>\mathrm{p})$. グループIV，Vで 男子の值は低くなるが，男女間の傾向線には有意差を認 めない $(\mathrm{p}>0.05)$. y は排尿率 $\mathrm{ml} / \mathrm{sec}, \mathrm{x}$ はグループを 示す.

3. 最大排尿率 (maximum flow rate)

総排尿量と正の相関を示す (Fig. 4, 右).男女の傾向 線はそれぞれ

$$
\begin{aligned}
& y=4 x+12.1 \\
& y=6.6 x+10.2
\end{aligned}
$$

となり各々有意であつた $(0.01>\mathrm{p})$. y は排尿率 $\mathrm{ml} / \mathrm{sec}$ ， $\mathrm{x}$ はグループ. 女子の值はグループ II ，III，IV，Vで男 子より有意に大きく（ $\mathrm{t}$ 検定，0.05又は $0.01>\mathrm{p})$, 又男 女間の傾向線でも有意差を認める $(0.05>\mathrm{p})$.

4. 最大排尿率 までの 時間と時間百分率 (time and time percent at maximum flow rate)

男子では総排尿量と相関を示すも，女子では 5 秒が上 限である (Fig. 5, 左).男女の傾向線はそれぞれ

$$
\begin{aligned}
& y=1.1 x+2.6 \\
& y=0.64 x+2.5
\end{aligned}
$$

となるｙ は時間（see）, x はグループ. 男子の傾向線 
Fig. 4. Average flow rate (left) and maximum flow rate (right) are correlated with the total urinary volume in both sexes. Sex difference is statistically significant in maximum flow rate.
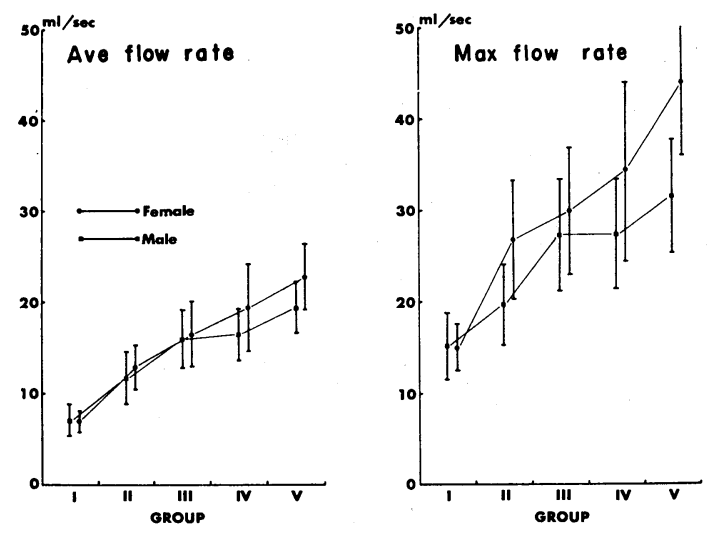

Fig. 5. Time at maximum flow rate (left) is proportional to the total urinary volume in male, but not in female. Flow rate reaches the maximum in one third of total voiding time (right).

\section{Time \& Time \% at MFR}
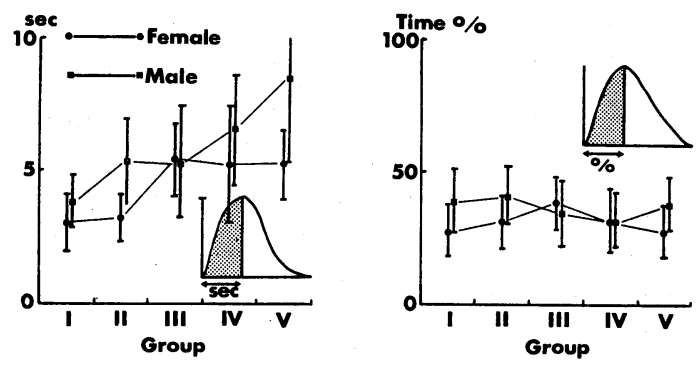

は有意であるが $(0.01>\mathrm{p})$ ，女子ではグループIV, Vの 值が低下し有意性を認めない（ $\mathrm{p}>0.05)$. 時間百分率は 総排尿時間に 対する割合を示す. 総排尿時間の約 $1 / 3$ で 排尿率は最大となる (Fig. 5, 右).

\section{5. 最大排尿率までの排尿量と排尿量百分率}

(volume and volume percent until time of maximum flow rate)

最大排尿率までに排泄される尿量は総排尿量と正の相 関を有する (Fig. 6, 左).男女の傾向線はそれぞれ

$$
\begin{aligned}
& y=35.3 x-4.4 \\
& y=31.1 x-4.2
\end{aligned}
$$

となり各々有意であつた $(0.01>\mathrm{p})$. 男女間の傾向線に は有意差を認めない $(\mathrm{P}>0.05)$. y は排尿量 $(\mathrm{ml}), \mathrm{x}$
Fig. 6. Volume until time of maximum flow rate (left) is correlated with the total urinary volume in both sexes. Approximately 40 percent of total volume is evacuated until time of maximum flow rate (right).

\section{Vol 8 Vol \% of MFR}
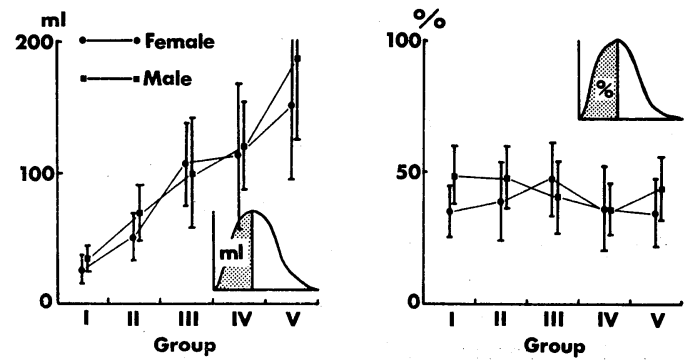

Fig. 7. Volume (left) and volume percent (right) for the first 1 to 5 seconds are illustrated.
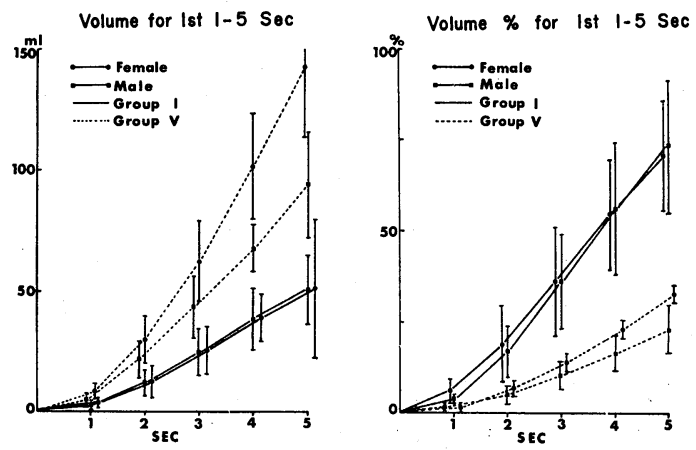

はグループを示す．Fig. 6，右図は膀脱容量のいかんを 問わず，その $40 〜 45 \%$ が最大排尿率にいたる間に排泄さ れることを示している。

\section{6. $1 \sim 5$ 秒後までの排尿量亡排尿量百分率}

(volume and volume percent for the first 1 to 5 seconds)

総排尿量が多いほど又排尿開始後の経過時間が長い汪 ど，最初の 5 秒間に排泄される尿量は多くなる（Fig. 7, 左). グループ I では男女間に差を認めないが，グル 一プVでは 3 秒以後に有意差をもつて女子の方が多く排 泄される（0.05又は0.01 >p）. 排尿量百分率の 5 秒後で はグループ I はすでに70\%が排泄されているが，グルー プVではまだ25\%しか排尿されていない(Fig. 7, 右). なおグループII，III，IVの值は図中のＩとＶの間に 在 る. 
Fig. 8. Time (left) and time percent (right) in relation to volume percent are illustrated.
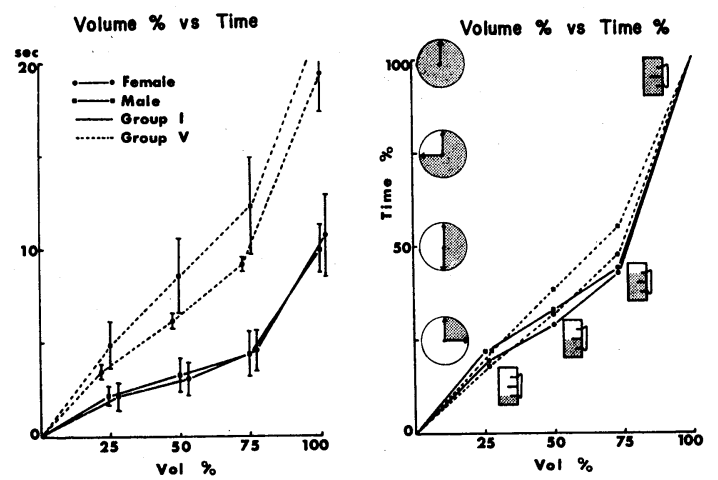

Fig. 9. Standardized flow curves based upon computed data.
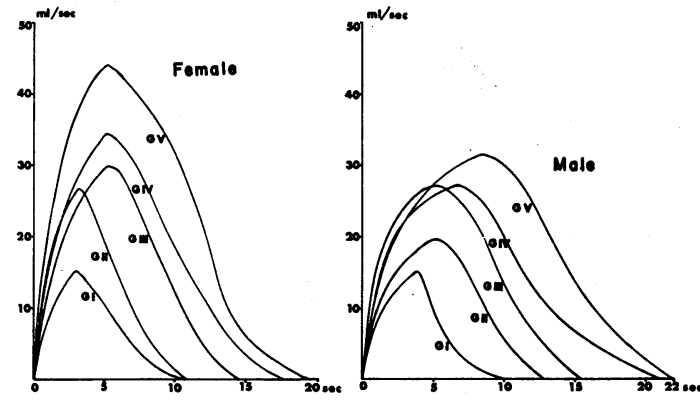

7. $25 \%, 50 \%, 75 \%$ 排尿量に要する時間と時間百分率 (time and time percent at 25\%-, 50\%-, 75\%-totalvolume)

所要時間は総排尿量と正の相関を示す (Fig. 8, 左). 膀脱容量の $50 \%$ を排泄するのにグループ I では 3 秒,
グループ Vでは $6 〜 9$ 秒を必要とする, 排尿量と排尿時 間との関係は両者を百分率で比較するとより明確となる

(Fig. 8, 右).総排尿量の $25 \%$ は総排尿時間の $1 / 5 て ゙, 50$ \%は1/3で，75\%は1/2で排泄される。

8. コンピューター解析による標準化排尿曲線

(standardized flow curve based upon computed data)

コンピューター計算された総排尿時間，最大排尿率， 経時的排尿率の各平均値をなだらかな曲線で結び，標準 化排尿曲線を作成した（Fig. 9)．男女共にグループ毎 の排尿曲線は互に相似形を示している. 男子排尿曲線終 末に通常認める棘波は平均化され，このグラフには描写 されていない.最後に日常診療に参考となる 3 つの排尿 パラメーターを Table 3 に示す（小数第 1 位を 4 捨 5 入).

\section{討 論}

日常我々は排尿曲線を定量的というむしろ定性的，視 覚的に認識し評価している．尿線中絶は容易に識別可能 である．しかし最大排尿率，平均排尿率，排尿時間の各 パラメーターは性別, 総排尿量と強く相関し, 標準值と 比較することなく見過ごすことが多い，本論文は健康日 本人男女の排尿運動におけるこれらの值を明確にし，さ らに経時的排尿量の変化を分析し報告した．排尿量を一 秒毎に測定する方法は1967年 Koontz \& Roman ${ }^{7)}$ によ り報告された，回転ドラムの周囲に60本のガラス管を装 置し，このドラムを60秒で 1 回転させる.これは単純明 確な方法で各ガラス管内の 尿量をグラフ用紙に記入す れば，経時的排尿量と共に排尿率が直らに判明する. Whitaker $^{8)}$, Edwards ${ }^{9)}$ も同じ測定法を発表した。しか し自動記録計が無く又60秒以上にわたる排尿には無効で ある等の欠点を有し，この方法による排尿パラメーター

Table 3. Standard values of 3 parameters found in normal Japanese men and women aged from 18 to 45 . The urinary flow curve has been obtained through Mictiograph (DISA, 14F43), where voiding was performed with abdominal strain.

\begin{tabular}{c|c|c|c|c|c|c}
\hline \multirow{2}{*}{$\begin{array}{c}\text { Urinary } \\
\text { volume }\end{array}$} & \multicolumn{2}{|c|}{$\begin{array}{c}\text { Total voiding } \\
\text { time (sec) }\end{array}$} & \multicolumn{2}{c|}{$\begin{array}{c}\text { Maximum flow } \\
\text { rate (ml/sec) }\end{array}$} & \multicolumn{2}{c}{$\begin{array}{c}\text { Average flow } \\
\text { rate (ml/sec) }\end{array}$} \\
\cline { 2 - 7 } & Male & Female & Male & Female & Male & Female \\
\hline $50 \sim 99 \mathrm{ml}$ & $10(1)^{*}$ & $11(2)$ & $15(4)$ & $15(3)$ & $7(2)$ & $7(1)$ \\
\hline $100 \sim 199 \mathrm{ml}$ & $13(2)$ & $11(2)$ & $20(5)$ & $27(7)$ & $12(3)$ & $13(3)$ \\
\hline $200 \sim 299 \mathrm{ml}$ & $15(2)$ & $15(4)$ & $27(6)$ & $30(7)$ & $16(3)$ & $17(4)$ \\
\hline $300 \sim 399 \mathrm{ml}$ & $21(4)$ & $18(5)$ & $29(6)$ & $34(10)$ & $17(3)$ & $20(5)$ \\
\hline $400 \sim 499 \mathrm{ml}$ & $22(4)$ & $19(2)$ & $32(6)$ & $44(8)$ & $19(3)$ & $23(4)$ \\
\hline
\end{tabular}

* Standard deviation 
の分析報告はない、コンピューター解析による排尿量の 経時的連続的測定法は生理的排尿に伴う新しいパラメー ターの検討を可能にした。すなわち最大排尿率までの排 尿量 (Fig. 6)，1～5秒後の排尿量 (Fig. 7)，一定排 尿量とそれに要する排尿時間の相関関係 (Fig. 8) の 3 つである. 最大排尿率までの排尿量は総排尿量との間に 正の相関を有する. Susset 等泉もこのパラメーターを報 告しているが，人種による差は汪とんどない。一定排尿 量とそれに要する時間の相関は極めて興味深い，膀胱容 量と性別のいかんを問わず，排尿量の50\%は総排尿時間 の1/3で，75\%は1/2で排泄される。例えば400 $\mathrm{ml}$ を20秒 間で排泄する健康人は前半の 10 秒で $300 \mathrm{ml}$ を後半の 10 秒 で $100 \mathrm{ml}$ を排尿する．乙たがつて平均排尿率は前半 30 $\mathrm{ml} / \mathrm{sec}$ から後半 $10 \mathrm{ml} / \mathrm{sec}$ 一と低下する.

総排尿時間, 平均排尿率, 最大排尿率の 3 つは外来で 定量的に比較検討が可能である (Table 3)。これらの傾 向線はいずれも有意性を有し，総排尿量とは直線関係に あるといえる，黑田1 の報告した健康男子の平均・最大 排尿率はほ湆著者のデータに重複するが，排尿量との 相関については検討されていない。これら 3 パラメー ターをカナダ人男子と比較してみると，值は相互に極め て類似している2)．男子に括汀る最大排尿率までの時間 （Fig. 5) は有意な傾向線を示し，総排尿量との間に正 の相関を有する。一方女子の所要時間は 5 秒が上限であ り，傾向線には有意性を認めなかつた。しかしこの傾向 線以外はすべて総排尿量との間に相関を示すことより， これは単にグループVの資料数 (Table 1) が少ないた め偶然に発生したものと推定する。

Susset 等 $^{2}{ }^{2}$ は男子排尿曲線での 排尿 2 秒後排尿率を総 排尿量と相関させグラフに描写した。この曲線は総排尿 量 $150 \mathrm{ml}$ と $350 \mathrm{ml}$ で $2 つ$ 頂点を作り，その間に谷を 形成したが，その生理的意義は不明と報告した。著者は 排尿後 $1 \sim 5$ 秒の排尿率をグラフに描きその凹凸につい て検討を加えた。男子排尿率曲線は 5 本共に $240 \mathrm{ml}$ (グ

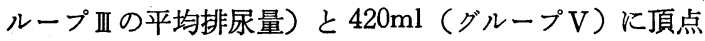
を，340ml（グループVI）に谷を形成していた（Fig. 10 , 左). 女子では 2 秒, 3 秒後排尿率で総排尿量 $230 \mathrm{ml}$ (グループIII) に谷が形成された (Fig. 10，右).しか し男女いずれの場合にも頂上と谷の值には統計的有意差 が証明されず $(p>0.05)$ ，この現象に特別な意義を見つ けることは妥当でない。

性別：女性の尿道は男性に比べて短かくて太く, 又屈 曲も少ない。尿流線のもつエネルギーは尿道粘膜との摩
Fig. 10. A drop is observed in the flow rate curve in both sexes. No signiffcaht meaning can be drawn from this phenomenon.

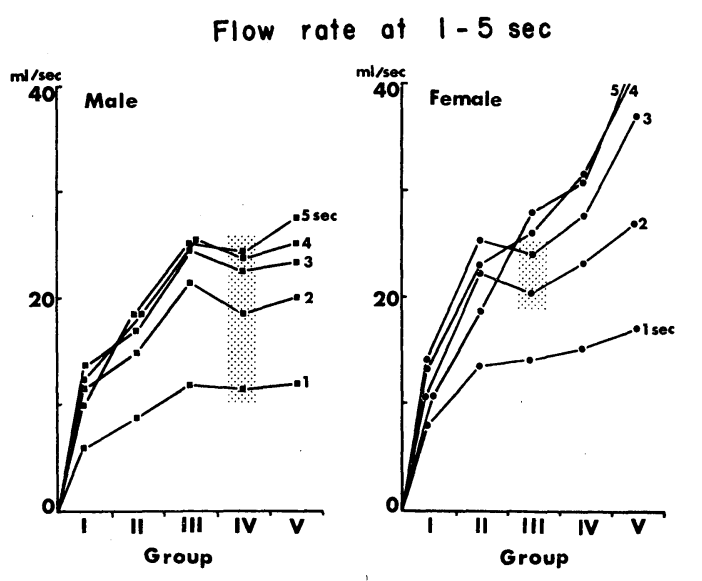

擦，尿流速度，尿流線の方向転換度に比例し，尿道直径 の 4 乗に反比例して減弱する ${ }^{10)}$ 。この結果女性の 尿線 エネルギー虽失度は男性よりも一般に少ないといわれ $3^{11)}$ 。事実，最大排尿率は女性の值 が 統計的有意差を もつて男性を凌駕していた (Fig. 4, 右). 更に女性排尿 曲線の排尿量係数が 1.0 以下に多く分布していたことは (Fig. 2)，次注述べる Mictiograph の特性より女性尿 線のもつエネルギーが大きいことを示唆するものであ る.

加㱓 : Drach \& Binard $^{12)}$ によれば10歳以後では, 30 歳毎の加齢と共に最大排尿率は $10 \mathrm{ml} / \mathrm{sec}$ づつ低下する といわれる.これは利尿筋の機能的機質的変化に基づく 膀胱収縮力の低下と ${ }^{13)}$, 男性では50歳頃より始まる前立 腺肥大のためであろう．検查対象者の年齢は18～45歳で あり，加齢の影響は除外できる。

Mictiograph の特性 : 排尿量係数は0.5 1.3k分布し (Fig. 2)，最終的誤差許容範囲を土15\%に限定した結 果男子では119資料中23（19\%）が女子では130資料中50 （38\%）が棄却された（Table 1)，女子の棄却率は有意 に男子より高い $\left(\mathrm{X}^{2}\right.$ 検定, $\left.0.005>\mathrm{p}\right)$. 排尿量係数が広 く分散し，男女間での棄却率が異なるのは何故であろら か? 尿流線のもつエネルギーが男女間で異なり，このた め Mictiograph の反応性に差が生ずるのではないかと考 えた．Fig. 11飞示す実験装置を組み立て，水を定常流 (31 $\mathrm{ml} / \mathrm{sec})$ で流して速度 Vを変化させ，尿流トランス デューサーの反応を検定した。速度 $\mathrm{V} は$ 次の 2 成分の和 である。 
Fig. 11. Experimental study of accuracy of Mictiograph.

\section{Experimental Design \\ Flow Rate, $31 \mathrm{ml} / \mathrm{sec}$}
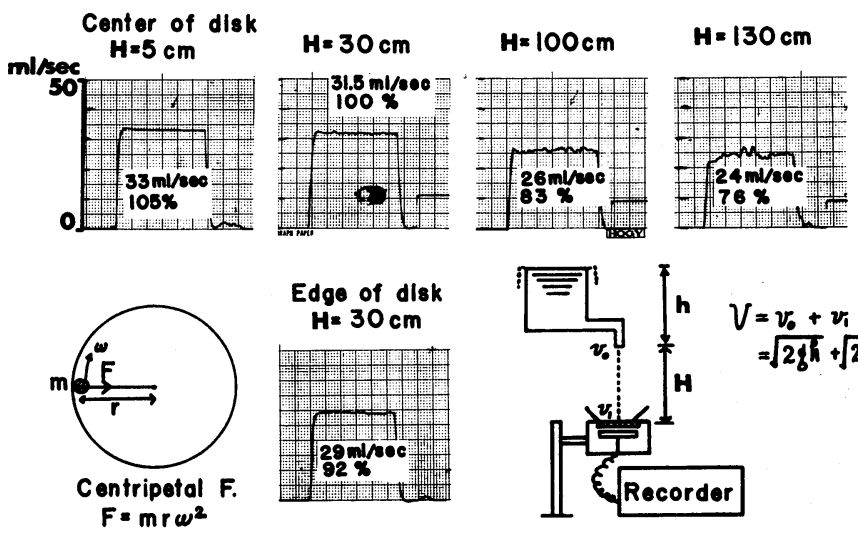

$\mathrm{v}=\mathrm{v}_{0}+\mathrm{v}_{1}$

$\mathrm{v}_{0}=\sqrt{2 \mathrm{gh}}$

$\mathrm{v}_{1}=\sqrt{2 \mathrm{gH}}$

$\mathrm{v}_{0}$ は貯水ビン先端での速度， $\mathrm{v}_{1}$ は距離 $\mathrm{H}$ で生ずる速 度, $\mathrm{h}$ と Hは図に示した距離である. 距離 $\mathrm{h}$ は固定し $\mathrm{H}$ を $5 \mathrm{~cm}, 30 \mathrm{~cm}, 100 \mathrm{~cm}, 130 \mathrm{~cm}$ と変化させ，定常流を回 転円盤の中心へ落下させた. 定常流に反応した Mictiograph の指す値Wは Fig. 11, 上段に示した. $30 \mathrm{~cm}$ で の反応は良好で $31.5 \mathrm{ml} / \mathrm{sec}$ と標示される。これより距 離が短かくなるとプラスの，長くなるとマイナスの誤差 (+ $5 \sim-24 \%)$ が生ずる. Wと $\mathrm{H}$ との間には負の相関 が成立する。

$$
\mathrm{W}=\frac{-7.5}{100} \mathrm{H}+33.2
$$

回転円盤に加わる力 $\mathrm{F}$ は次のように一般化される。

$$
\mathrm{F}=\frac{\mathrm{mV}-\mathrm{mV}}{\Delta \mathrm{t}}
$$

$\mathrm{m}$ は質量， Vは円盤にあたる前の尿流速度， $\mathrm{V}^{\prime}$ は円盤 から跳ね返つた後の速度で， $\Delta \mathrm{t}$ は円艋への衝突時間で ある. 円艋に加わる反作用力 $\mathrm{F}^{\prime}$ は

$$
\mathrm{F}^{\prime}=-\mathrm{F}=\frac{\mathrm{mV}-\mathrm{mV}^{\prime}}{\Delta \mathrm{t}}
$$

となる. Mictiograph の指す值Wは公式（8）上り

$$
\mathrm{W}=\frac{\mathrm{mV}}{\Delta \mathrm{t}}
$$

となるべきである．次に $\mathrm{H}=30 \mathrm{~cm}$ で定常流 $(31 \mathrm{ml} / \mathrm{sec}$ ) を, 回転円盤の外縁へ落下させた. Mictiograph の標示 は中心へ落下させた場合のー8\%となつた（Fig. 11，下 段).これは向心力 F (centripetal force)

$$
\mathrm{F}=\mathrm{mr} \omega^{2}
$$

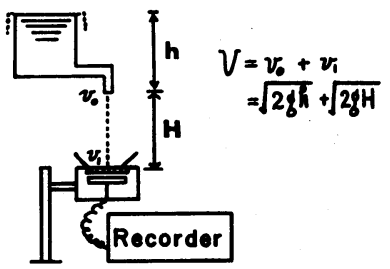

の影響をらけるためである。 $\mathrm{m}$ は質量, $\mathrm{r}$ は半径, $\omega$ は 角速度を示す．尿線落下点が円盤の外側になるほど， $\mathrm{r}$ は大きくなり向心力は増大する．最後に尿流量変化に対 する反応性を検定した．Hを通常の外尿道口と回転円盤 との距離に相当する $30 \mathrm{~cm}$ に固定し, 水流線は円盤の中 心落下させ，流量を8 30 $\mathrm{ml} / \mathrm{sec}$ の範囲で10通りに変 化させた。生じた誤差は $0 \sim+7 \%$ て平均 $+3 \%$ と計 算された。このように Mictiograph の反応性に影響を拉 よぼすものは尿流速度, 向心力, 尿流量の 3 要因と判明 した。尿流量の変化に対する反応性は良好であり，この 関係は速度Vを定量と想定すれば公式 (9)によつて示さ れている。一方尿流速度と向心力の 変化に 対する追従 性は不良で，何ら補正能力を備觉ず，その結果は公式 （9），(10）と逆相関を示す. 逆説的には Mictiograph が尿流量計と称される以上，流量以外の要因に追従でき ない無能力性を責めることはできない，排尿運動を総合 的かつ高精度に分析把握するには尿流力 (urinary stream force）の測定をも同時に括こなら dynamometer ${ }^{1014)}$ が 必要となる. 排尿量係数の誤差 $\pm 15 \%$ の内, $\pm 10 \%$ は理 論上 Mictiograph に由来するものと考光た。松田等 ${ }^{65}$ は Mictiograph の尿流量と向心力の変化に対する反応につ いて検討を加えたが，尿流速度については全く考慮を払 つていない.

\section{誤差の起源}

和式便器：西洋式便器は剧部に不潔感を覚えるとの理 由で採用せず，和式便器を 用い蹲踞位にて排尿せしめ 
た，尿流が便器の壁面をつたわり，反応時間の遅延，排 尿時間の延長等が予想された。しかし実際には女性の長 年の経験により「排尿時には尿の跳返りを最小限に抑兄 るよう，無意識に体位を変換している」との証言を多く 得た。すなわち排尿は前方排出孔を目がけておこなわ れ，排尿曲線に与える影響はほとんど無視できるものと 考えた。

尿流量計 :データのすべてを生み出す重要な器械であ る故，松田等 ${ }^{6}$ の報告にしたがい、尿流量変化に対する精 度検定は 2 カ月に 1 度抗こなつた．通電後，時間の経過 と共にゼロ基準線と較正幅がしばしば浮動するため，原 則として排尿前には zero ッマミと gain ッマミにて必 ず微調整を接こなつた：排尿曲線再現性の本質的欠陥は すでに述べた。総排尿量は $1000 \mathrm{ml}$ メスシリンダーを用 い測定した。目盛は $25 \mathrm{ml}$ 毎に区切られ，10 $\mathrm{ml}$ 以下の值 を正確に判読することはできない，総排尿量 $100 \mathrm{ml}$ では $\pm 10 \%$ の $500 \mathrm{ml}$ では土 $2 \%$ の測定誤差が生じ, 平均士 $5 \%$ と推定した。

スライド拡大投影：10mm 毎に細い縦線を引いた薄い ビニールシートをグラフペン XY 座標值測定盤上へ固 定し，記録紙の $3 \mathrm{~mm}$ (1 秒) が綎線に合致するようス ライドを投影した。データー相互間の誤差はない。

グラフペン操作：最大排尿率は排尿曲線の最高点に一 致する。一方グラフペンは排尿曲線を一秒毎に記録する 故，本来の值を正確に計測しないことがある，例えば Fig. 1 の $\mathrm{C}^{\prime}$ 点がC点として記録される.現実にはこの 差は $1 \mathrm{ml} / \mathrm{sec}$ 以下であり, 最大排尿率 $27 \mathrm{ml} / \mathrm{sec}$ (男女の 平均値, Table 3) で生ずる 誤差は $2 \%(0 \sim 4 \%)$ と 予想される. 同様に総排尿時間は本来 $\mathrm{AG}^{\prime}$ のものが $\mathrm{AG}$ として過大と記録される (Fig. 1).この值は 1 秒以下 で，総排尿時間15秒（男女の平均值, Table 3) で生ず る誤差は平均 $3 \%(0 ６ \%)$ と想定される。

コンピューター測定尿量 : コンピューターによる尿量 計算は公式（6)に基づき，三角形と台形の総和として求 められ，理論的には実測尿量より小さな值となる．男女 各々一名で尿量を $1 \mathrm{ml}$ の単位まで測定し，排尿量保数 を求めた. 男子 (A.K., 37歳) では1.1 \pm 0.1 (平均值士

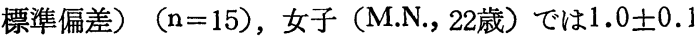
$(\mathrm{n}=12)$ となつた。男子ではコンピューター 測定尿量 の方が大きい值であつた．これは外尿道括約筋と球海綿 体筋の収縮による棘波を男子排尿曲線の終末に認め，こ の山の部分をも計算するためと推測される (Fig. 1).

上述の如く誤差の源として最もその影響力が大きいの
は Mictiograph そのものであり，次いで尿量実測；グラ フペン操作に基づくものである.排尿量係数はこれらの 誤差を一括内包している．したがつて Mictiograph によ る誤差を $\pm 10 \%$ ，その他の誤差を士 $5 \%$ と想定し，その 和土15\%を排尿量係数の信頼限界とした。

\section{要 約}

デジタルコンピューターを用い，排尿曲線より得られ る35の排尿パラメーターについて，性別・総排尿量との 相関について統計的分析を試みた。尿流量計は Mictiograph (DISA，14F43) を用い，18４5歳150名の健康男 女より 500枚の排尿曲線を入手した．XY 座標值測定盤 上に拡大投影した排尿曲線上の点を 1 秒每にグラフペン で検出し，1 秒毎の排尿率のみならず排尿量も連続的に 計測し249資料をコンピューターヘ入力した.

Mictiograph は尿量の変化には良好な反応を示す。乙 かしこれに尿流速度と向心力の変化が加わると追従性は 不良となり，排尿率と排尿量はその変化量に反比例して 標示される. 排尿量係数（コンピューター測定尿量/実 測尿量）を指標として誤差範囲を検出すると0.5〜1.3に 分散していた．誤差の許容範团を土15\%に限定した結果 53資料が棄却され，残る176資料に 基づき今回の統計的 分析を拈こなつた。

1. 総排尿時間, 平均排尿率, 最大排尿率 : 男女共に 総排尿量との間に正の相関を有する．男女間の値に有意 差を認めたのは最大排尿率のみで，女性の方が大きい。

2. 最大排尿率までの時間と時間百分率 : 男子は総排 尿量との間に相関を示す。女子の 值は 5 秒が 上限であ り，総排尿量との間に有意な相関を認めない，総排尿時 間の約 $1 / 3$ で排尿率は最大となる。

3. 最大排尿率までの排尿量と排尿量百分率 : 男女共 に総排尿量との間に正の相関を示し，最大排尿率までに 総排尿量の約 $40 \%$ が排泄される。

4. $1 \sim 5$ 秒後までの排尿量と排尿量百分率 : 総排尿 量と排尿開始後の経過時間とに比例する。 5 秒後にグル ープ I (総排尿量, 50〜99ml) では総排尿量の70\%が, グループV $(400 \sim 499 \mathrm{ml})$ では総排尿量の $25 \%$ が排泄さ れる。

5. 排尿量と排尿時間との相関 : 性別，総排尿量の如

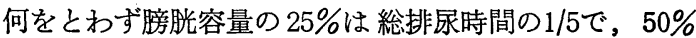
は1/3で，75\%は1/2で排泄される。

6. 一般に女性の排尿力は男性よりも大きい。

7. 排尿後 $1 \sim 5$ 秒の排尿率と排尿量との相関図を成 作すると，男子ではグループIV（1～5秒後）に，女子 
ではグループII（2 と 3 秒後）に曲線の下降を認めた。 統計的有意差はなく，この現象に特別な意義を見つける ことは妥当でない。

8. Mictiograph は排尿の定性的検査法として極めて 簡便であり有用である。しかし定量的に排尿パラメータ 一を分析するにはその機構上に問題点がある.

稿を終るに際し，御指導御校閲をいただいた三矢英輔 教授に深甚なる謝意を表します。労働福祉事業団労炎義 肢センター職員松尾功一, 小熊和彦両氏にはコンピュー タープログラミングを担当していただいた．更に中部労 㷋病院泌尿器科部長鳥居肇博士, 名古屋大学医学部第三 内科佐藤祐造博士, 当教室員各位など多くの方々の御協 カに感謝します。

\section{文献}

1）黒田清輝：泌尿紀要， 15，779，1969.

2) Susset, J.G., Picker, P., Kretz, M. and Jorest, R.: J. Urol., 109, 874, 1973.

3) Scott, F.B.: Medical Record and Annals, 60, 263, 1967.
4) Susset, J.G., Shoukry, I., Schlaeder, G., Cloutier, D. and Dutartre, D.: J. Urol., 111, 504, 1974.

5) Madersbacher, H.: Paraplegia, 13, 95, 1975.

6) 松田 稔, 森 義則, 高橋香司, 永田 筆, 坂 口 強, 拍井浩三: 日泌尿会誌, 64, 837,1973.

7) Koontz, W.W. and Rowan, G.A.: Invest. Urol., 5, 35, 1967.

8) Whitaker, R.H.: Grit. J. Urol., 42, 203, 1970.

9) Edwards, L.: Brit. J. Urol., 43, 226, 1971.

10) Gleason, D.M. and Bottaccini, M.R.: in Hydrodynamics of Micturition, Hinman, F., Jr., Boyarsky, S., Pierce, J.M. and Zinner, N.R., p. 175, C.C. Thomas Publisher, Springfield, 1971.

11) Byrne, J.C., Bottaccini, M.R. and Gleason, D.M.: Invest. Urol., 10, 221, 1972.

12) Drach, G.W. and Binard, W.: J. Urol., 115, 175, 1976.

13) Brocklehurst, J.C.: Geriatrics, 27, 154, 1972.

14) Whitaker, J. and Johnston, G.S.: Invest. Urol., 3, 379, 1966.

（1977年 3月10日受付） 